\title{
PENDIDIKAN KARAKTER DALAM TAFSIR AL-HUDA
}

\author{
Novita Siswayanti \\ Peneliti Puslitbang Lektur dan Khazanah Keagamaan \\ Badan Litbang dan Diklat Kementerian Agama RI \\ Jl. MH Thamrin Nomor 06 Jakarta
}

Abstrak

Penelitian ini berupaya untuk mengkaji pendidikan karakter dan implikasinya yang terdapat pada TafsirAl-Huda. Metode dalam penelitian ini adalah metode analisis isi (content analysis) dengan pendekatan hermeunetika, yakni menafsirkan simbol berupa teks untuk dicari arti dan maknanya. Dari hasil penelitian ini dapat disimpulkan bahwa Tafsir Al-Huda berperspektif budaya Jawa yang bersifat kultural kontekstual serta akomodatiif dan integratif interkonektif. Tafsir Al-Huda mentransformasikan nilai-nilai budi pekerti Jawa yang merupakan akumulasi dari cipta-rasa-karsa yang diaktualisasi kan ke dalam sikap, kata-kata, dan tingkah laku seseorang. Pendidikan karakter dalam tafsir ini dipandang sebagai aktualisasi iman yang yang merepresentasikan tabiat, watak, akhlak, dan moral, sekaligus mencerminkan sikap batin yang melahirkan akhlak yang baik, rajin beribadah, jernih akal budinya, dan banyak berbuat kebajikan.

Keywords : Pendidikan Karakter, Karakter, Tafsir Al-Huda

\section{Abstract}

Tafsir Al-Huda tafsir Al-Qur'an written in Javanese is one of the treasures of Indonesia's religious and philosophical thought in the context of projecting the struggle between Al-Quran and Javanese cultural heritage possessed by the author. Tafsir Al-Huda exists as a guidebook for the practice of the Qur'an, containing messages of moral values or akhlakul karimah as the main basis for character education. This study sought to examine the educational character and implications contained in Tafsir Al-Huda. This research uses a content analysis method with hermeneutics approach, interpreting the symbols in the form of text to search for meaning and significance. From the results, it can be concluded that the Tafsir Al-Huda contains a Javanese cultural perspective which shows contextual, integrative and accommodative cultural interconnectivity. Tafsir Al-Huda transforms the character values of Java which is an accumulation of the belief and synchronicity actualized into attitudes, words, and behavior. Character education is the actualization of faith that represents the nature, character, and morals, and reflects the attitude of mind that gave birth to good morals, diligent worship, clear minds, and good deeds.

Keywords: Character, Islamic Education, Tafsir

\section{PENDAHULUAN}

\section{Latar Belakang Masalah}

Dalam UU No. 20 Tahun 2003 Bab 2 Pasal 3 termaktub bahwa Pendidikan Nasional berfungsi mengembangkan kemampuan dan membentuk watak serta peradaban bangsa yang bermartabat dalam rangka mencerdaskan kehidupan bangsa, bertujuan untuk berkembangnya potensi peserta

Naskah diterima 27 Mei 2013. Revisi pertama, 22 Juni 2013. Revisi kedua, 10 Juli 2013 dan revisi terahir 3 Agustus 2013. 
didik agar menjadi manusia yang beriman dan bertakwa kepada Tuhan Yang Maha Esa, berakhlak mulia, sehat, berilmu, cakap, kreatif, mandiri, dan menjadi warga negara yang demokratis serta bertanggung jawab. ${ }^{1}$ Dalam arti bahwa Pendidikan Nasional dapat diwujudkan dan dicapai melalui dua hal penting, yaitu peningkatan kompetensi dan pembentukan karakter yang merupakan satu kesatuan yang utuh. Sasaran pendidikan bukan hanya kepintaran dan kecerdasan (pemikiran), tetapi juga kepribadian yang tangguh, religious, bermoral, berbudi pekerti, mandiri dan dewasa dalam berperilaku.

Namun adalah sebuah ironi, di mana Indonesia selalu menjadi pemborong medali dalam setiap kompetisi olimpiade sains internasional, namun di sisi lain, kasus siswa-siswi cacat moral seperti siswi married by accident, kasus bullying, aksi pornografi, kasus narkoba, plagiarisme dalam ujian, dan sejenisnya, senantiasa marak menghiasi sejumlah media. Bukan hanya terbatas pada peserta didik, lembaga-lembaga pendidikan maupun instansi pemerintahan yang notabene diduduki oleh orang-orang penyandang gelar akademis, pun tak luput terjangkiti virus dekadensi moral. Bahkan Para stakeholders dan pendidik yang tadinya diharapkan menjadi ing ngarsa sung tulada, ing madya mangun karsa, tut wuri handayani, malah lebih menyuburkan slogan sarkastik: guru kencing berdiri, murid kencing berlari.

Meskipun founding father bangsa ini telah menggagas dan mengimplementasikan pendidikan karakter sebagai pilar pendidikan budi pekerti bangsa, namun semua itu tereduksi karena nafsu percepatan sains dan teknologi yang lebih menekankan kepada kognitif dan kesalahan pengguna tekhnologi dalam memanfaatkan dan memandang nilai filosofi fungsi teknologi. Untuk itu pendidikan karakter penting direvitalisasikan kembali sebagai upaya untuk menumbuhkan kepekaan

${ }^{1}$ UU Sisdiknas No.20 Tahun 2003, Kementerian Pendidikan Nasional Badan Penelitian dan Pengembangan Pusat Kurikulum, 2010, Pengembangan Pendidikan Budaya dan Karakter Bangsa, Jakarta dan tanggung jawab sosial, membangun kecerdasan emosional, dan mewujudkan peserta didik yang memiliki moral yang tinggi. Pendidikan karakter yang dapat menentukan kemajuan peradaban bangsa, yang tak hanya unggul, tetapi juga bangsa yang cerdas dalam pemikiran dan karakter.

Pendidikan karakter diselenggarakan sebagai suatu proses pembudayaan dan pem berdayaan peserta didik yang berlangsung sepanjang hayat. Pendidikan bukan hanya merupakan sarana transfer ilmu pengetahuan saja, melainkan sebagai sarana pem budayaan dan transformasi nilai (enkulturisasi dan sosialisasi) yang dapat menyentuh pada ranah nilai-nilai ketuhanan dan kemanusiaan. Transformasi nilai-nilai budi pekerti luhur yang memiliki relevansi tinggi bagi pengembangan kecakapan hidup (life skill) dapat digali dan dibentuk dari potensi kebudayaan lokal yang melekat dan dianut masyarakat dan juga menjadi tradisi di masyarakat. ${ }^{2}$

Salah satu potensi kebudayaan lokal yang merepresentasikan dan mengaktualisasi kan nilai-nilai pendidikan karakter kearifan lokal daerah adalah Tafsir Al-Huda. Tafsir Al-Qur'an yang mentransmisikan karakter budaya Jawa menuju tatanan kehidupan yang sesuai dengan nilai nilai ajaran Al-Qur'an tanpa harus meninggalkan warisan adiluhung dalam budaya Jawa. Dialektika Al-Qur'an dan nilai nilai budi pekerti budaya Jawa dalam Tafsir AlHuda merupakan proses pergumulan antara Al-Qur'an warisan etika budaya Jawa yang dimiliki pengarang dan kondisi sosial budaya Jawa yang melingkupinya. ${ }^{3}$

Nilai-nilai budi pekerti luhur yang terdapat pada Tafsir Al-Huda merupakan implementasi dari nilai-nilai budi pekerti Jawa yang dapat ditransmisikan dan direalisasikan menjadi pendidikan karakter. Realisasi pendidikan karakter yang digali dari Tafsir Al-Huda dapat

${ }^{2}$ Barnawi dan M. Arifin, 2011, Strategi dan Kebijakan Pembelajaran Pendidikan Karakter, Yogyakarta, Arruz Media, h. 24

${ }^{3}$ Imam Muhsin. 2010, Tafsir Al-Qur'an dan Budaya Lokal, Jakarta: Kementerian Agama, Balitbang Diklat, Puslitbang Lektur dan Khazanah Keagamaan, 2012, h.x 
dimulai melalui internalisasi nilai-nilai budi pekerti luhur Jawa dalam pembelajaran budaya Jawa dan pengembangan kultur sekolah. Dalam pem belajaran bahasa dan sastra Jawa, hendaknya dapat berlangsung melalui proses meaning making (membuat bermakna), sehingga akan terjadi internalisasi nilainilai dalam diri siswa. Pengembangkan kultur sekolah dapat dilakukan dengan cara memberi keteladanansecara langsung sesuai dengan nilai-nilai kultural bahasa dan sastra Jawa. ${ }^{4}$

Berdasarkan latar belakang yang telah diuraikan di atas, maka artikel ini menarik untuk mengkaji dan menelaah pendidikan karakter yang terdapat pada Tafsir Al-Huda untuk mewujudkan tujuan pendidikan yaitu peningkatan kompetensi dan pembentukan karakter

\section{Rumusan Masalah}

Untuk mengkaji pendidikan karakter yang terdapat pada Tafsir Al-Huda, beberapa masalah yang dapat dirumuskan pada penelitian ini adalah: 1. Siapa pengarang Tafsir Al-Huda dan bagaimana karakteristik Tafsir Al-Huda; 2. Apa saja pendidikan karakter yang terdapat pada Tafsir Al-Huda itu; 3. Apa saja pendidikan karakter dalam Tafsir Al-Huda yang dapat diterapkan di sekolah.

\section{Tujuan Penelitian}

Untuk mengetahui biografi singkat pengarang dan karakteristik Tafsir Al-Huda; b. Untuk mengetahui pendidikan karakter pada Tafsir Al-Huda; c. Untuk mengetahui pendidikan karakter pada Tafsir Al-Huda yang dapat diimplementasikan di sekolah.

\section{Signifikasi Penelitian}

Diharapkan dapat memberikan sumbangan dalam upaya membentuk watak manusia yang berbudi luhur dan berkepribadian, sehingga dapat membantu mewujudkan

${ }^{4}$ Saliman, 2011, Membangun Karakter Bangsa Melalui Bahasa Simbolik Jawa, h. 3 tujuan pendidikan nasional yaitu peningkatan kompetensi dan pembentukan karakter. Selain itu juga dapat memberikan sumbangan dan menjadi tawaran alternatif bagi upaya perbaikan moralitas bangsa.

\section{Metode Penelitian}

Dalam penelitian ini adalah metode analisis wacana (content analysis) dengan pendekatan hermeunetika, yakni menafsirkan simbol berupa teks untuk dicari arti dan maknanya. Carl Braathen hermeneutika adalah ilmu yang merefleksikan bagaimana satu kata atau satu peristiwa di masa dan kondisi yang lalu bisa dipahami dan menjadi bermakna di masa sekarang sekaligus mengandung aturanaturan metodologis untuk diaplikasikan dalam penafsiran dan asumsi-asumsi metodologis dari aktivitas pemahaman. ${ }^{5}$ Dalam penelitian ini berupaya mengungkapkan makna makna simbolik nilai-nilai pendidikan yang terdapat pada Tafsir Al-Huda dalam pembentukan pendidikan karakter.

Langkah-langkah penelitian analisis isi yang dilakukan menurut rancangan Krippendorff, meliputi: (1) Pengadaan data, Data-data terkait dengan pendidikan karakter dikumpulkan melalui data primer yaitu Tafsir Al-Huda dan data sekunder buku-buku filsafat dan budaya Jawa; (2) Validitas, untuk mengetahui ketepatan dalam mengartikan setiap kata dalam Bahasa Jawa ke dalam Bahasa Indonesia dan ketepatan dalam memaknai korelasi pendidikan karakter dalam Tafsir Al-Huda dan (3) Analisis terhadap isi dan pemaknaan kata-kata yang korelasi dengan pendidikan karakter dalam Tafsir Al-Huda ${ }^{6}$

\section{Kerangka Teori}

Kerangka teori yang menjadi landasan teori pada penelitian ini adalah:

${ }^{5}$ Mudjia Raharjo. 2012, Dasar-dasar Hermeneutika Antara Intensionalisme dan Gadamerian, Yogyakarta: ArRuzz Media, h. 30

${ }^{6}$ Klaus Krippendorf. 1980, Content Analysis: AN Introduction to Its Methodology London Baverly Hills: Saga Publication, h.61 


\section{Pendidikan Karakter}

Pendidikan merupakan usaha sadar dan terencana untuk mewujudkan suasana belajar dan proses pembelajaran agar peserta didik secara aktif mengembangkan potensi dirinya untuk memiliki kekuatan spiritual keagamaan, pengendalian diri, kepribadian, kecerdasan, akhlak mulia, serta keterampilan yang diperlukan dirinya dan masyarakat.

Karakter dalam Kamus Besar Bahasa Indonesia adalah sifat-sifat kejiwaan, akhlak atau budi pekerti yang membedakan seseorang dari yang lain, tabiat, watak. ${ }^{7}$ Menurut Wayne ada dua pengertian tentang karakter, yaitu: Pertama, menunjuk pada bagaimana seseorang bertingkah laku. Apabila berperilaku tidak jujur, kejam tentu orang tersebut memanifestasikan perilaku buruk. Sebaliknya, apabila seseorang berperilaku jujur, suka menolong, tentu orang tersebut memanifestasikan karakter mulia. Kedua, istilah karakter erat kaitannya dengan personaliti. Seseorang baru bisa disebut orang yang berkarakter apabila tingkah lakunya sesuai kaidah moral. ${ }^{8}$

Pendidikan karakter menurut Dirjen Dikti adalah pendidikan nilai, pendidikan budi pekerti, pendidikan moral, pendidikan watak yang bertujuan mengembangkan kemampuan anak didik untuk memberikan keputusan baik buruk, memelihara apa yang baik, mewujudkan dan menbarkan kebaikan dalam kehidupan sehari-hari dengan sepenuh hati. ${ }^{9}$

\section{Tafsir Al-Huda}

Tafsir Al-Huda salah satu khazanah tafsir Indonesia yang berbahasa Jawa karya Bakri Syahid Rektor IAIN Sunan Kalijaga Jogyakarta (1972-1976). Tafsir Al-Huda ditulis Bakri Syahid yang kehidupannya sejak lahir dan dibesarkan

${ }^{7}$ Departemen Pendidikan Nasional, 2008. Kamus Besar Bahasa Indonesia. Jakarta: PT Gramedia Pustaka Utama, Edisi Keempat, h. 623

${ }^{8}$ Megawangi, Ratna, 2008, Membangun SDM Indonesia Melalui Pendidikan Holistik Berbasis Karakter, www.usm. maine.edu.com, h. 1

${ }^{9}$ Dirjen Dikti, Pendidikan Karakter, www. kopertis8.0rg/.../Pendidikan\%20 dalam interaksi budaya Jawa. Tafsir Al-Huda merupakan proses pergumulan antara AlQur'an warisan budaya Jawa yang dimiliki pengarang dan kondisi sosial budaya Jawa yang melingkupinya. Tafsir Al-Huda tafsir Al-Qur'an yang dikarang BakriSahidyang bertujuan untuk pembentukan moral dan perilaku bangsa yang sesuai dengan Al-Qur'an dan berpegang teguh pada kepribadian nasional. Al-Qur'an adalah petunjuk dan penuntun tiap-tiap individu untuk membangun ketakwaan kepada Allah dan menyempurnakan budipekerti luhur serta budidaya manusia. Tafsir Al-Huda merupakan tafsir kontemporer berperspektif budaya Jawa yang bersifat kultural kontekstual serta akomodatif dan integratif interkonektif yang memuat nilai-nilai pembentukan karakter atau budi pekerti akhlak mulia. ${ }^{10}$

\section{HASIL DAN PEMBAHASAN}

\section{Tafsir Al-Huda dan Pengarangnya}

\section{Pengarang Tafsir Al-Huda}

Tafsir Al-Huda dikarang dan ditulis seorang purnawirawan militer dan juga Rektor IAIN Sunan Kalijaga Jogyakarta (1972-1976) yang bernama Kolonel (Purn.) Drs. H. Bakri Syahid. Bakri dilahirkan pada Hari Senin Wage tanggal 16 Desember 1918 M di Kampung Suronatan, Kecamatan Ngampilan Kotamadya Jogyakarta. Ayah nya bernama Muhammad Syahid dan ibunya bernama Dzakirah. Bakri dilahirkan dan dibesarkan dalam lingkungan keluarga Jawa yang agamis, dan sangat menjunjung tinggi nilai-nilai budi pekerti budaya Jawa dalam kehidupan sehari-hari.

Bakri Syahid mulai menimba ilmu di Kweekschool Islam Muhammadiyah (sekarang Madrasah Muallimin)dan lulus padatahun 1935. Pada tahun 1957, Bakri Syahid melanjutkan pendidikan di Fakultas Syariah IAIN Sunan Kalijaga Jogjakarta. Kemudian tahun 1964, Bakri melanjutkan pendidikan militer di Fort Hamilton, New York Amerika Serikat. Setelah

${ }^{10}$ Syahid, Bakri, 1979, Tafsir Al-Huda Tafsir Qur'an Basa Jawi, Yogyakarta: Persatuan Press, h. 7 
menyelesaikan sekolah di Madrasah Muallimin hingga tahun 1942, Bakri pernah menjadi Pengajar H.I.S Muhammadiyah sepanjang Surabaya dan Sekayu Palembang sampai tahun 1942. Bakri Syahid memulai karirnya di militer dan diangkat menjadi kepala Pusroh TNI AD di Jakarta hingga ia menjabat sebagai Wakil Kepala Pusroh Islam Angkatan Darat dan Asisten Sekretaris Republik Indonesia. Bakri juga menjabat sebagai Rektor IAIN Sunan Kalijaga Jogyakarta (1972-1976) dan anggota MPR RI dari fraksi ABRI tahun 1977. ${ }^{11}$

Bakri Syahid memiliki perhatian besar terhadap dunia akademik dan intelektual. Di sela-sela kesibukannya Bakri juga hobi dan gemar menulis dan berprofesi sebagai wartawan. Adapun karya-karya Bakri Syahid adalah Tata Negara RI, Ilmu Jiwa Sosial, Kitab Fikih, Kitab 'Aqaid, Pertahanan Keamanan Nasional, Ilmu Kewiraan, dan ideologi Negara Pancasila. Bakri Syahid dikenal sebagai seorang pemimpinyang memilikisifat ksatria adiluhung Jawa, berbudi pekerti luhur, penyabar, lembah manah, serta jauh dari sikap adigang adigung adiguna, welas asih dan memiliki solidaritas yang tinggi kepada sesama. ${ }^{12}$

\section{Karakteristik Tafsir Al-Huda}

Tafsir Al-Huda ditulis Bakri Syahid sejak pertama kali sebagai pegawai ABRI di Sekretaris Negara pada tahun 1970 sampai menjadi rektor IAIN Sunan Kalijaga. Dan tafsir ini sempurna diselesaikan pada tahun 1977 (masa orde baru). Baru diterbitkan pada tahun 1979 oleh percetakan offset "Persatuan" Yogyakarta.Ada tiga alasan atau penyebab yang melatarbelakangi Bakri Syahid menulis Tafsir Al-Huda, yaitu: Pertama, pembentukan moral bangsa yang sesuai Al-Qur'an. Menurutnya, adalah tugas mulia, membangun bangsa dan perilaku bangsa dengan tetap berpegang pada kepribadian nasional. Kedua, tafsir ini sebagai bentuk silaturrahmi Bakri kepada sahabatsahabat seperjuangan baik di transmigrasi, kenalan lama di Suriname, Malaysia,

\footnotetext{
${ }^{11} \mathrm{Ibid}$, h. 9

${ }^{12}$ Ibid, h. 9
}

Singapura, dan Filipina teman-teman jama'ah haji (1955 dan 1971), saudara-saudara di Mekah dan Madinah asal Jawa yang membutuhkan tafsir yang disalin ke dalam bahasa Latin dan diterjemahkan ke bahasa Jawa. Ketiga, minimnya tafsir berbahasa daerah, seperti yang diungkapkan Majelis ulama Daerah Yogyakarta bahwa masih sangat sedikit sekali tafsir AlQur'an yang menggunakan bahasa daerah, khususnya Jawa. Dimana penduduknya masih kurang bisa memahami bahasa Indonesia dan lebih memilih bahasa daerah dibanding bahasa Indonesia. Oleh karena itu, diharapkan dengan adanya tafsir ini, akan menambah khazanah Tafsir di Indonesia sekaligus menjadi sarana membangun moral dan budi pekerti bangsa.

Secara fisik Tafsir Al-Huda berbentuk buku yang dicetak satu jilid di atas kertas buram dengan cover bewarna hijau. Tafsir Al-Huda memiliki ukuran panjang $24 \mathrm{~cm}$, lebar 15,5 $\mathrm{cm}$, ketebalan $5,5 \mathrm{~cm}$, dengan jumlah halaman seluruhnya sebanyak 1376 halaman. Pada sampul depan bagian atas terdapat tulisan "AlHuda Tafsir Qur'an BasaJawi" dalam huruf latin, di bagian tengah terdapat tulisan "Al-Huda" dalam huruf Arab berbentuk lingkaran, dan di bawahnya berturut-turut terdapat nama pengarang dan nama penerbit buku. Tafsir AlHuda diterbitkan pada tahun 1983 sudah melalui proses tahqiq oleh Lajnah Pentashihan Mushaf Al-Qur'an dan isi terjemahannya merujuk kepada kitab Al-Qur'an dan Terjemahnya yang dikeluarkan oleh Departemen Agama. Pada Tafsir Al-Huda tertulis transliterasi bacaan AlQur'an ke tulisan aksara latin bahasa Jawa, Pada bagian-bagian tertentu terdapat penjelasan Penerjemahan Tafsir Al-Huda dipengaruhi oleh latar historis dan budaya sang penulis.

Secara substansi Tafsir Al-Huda memuat seluruh ayat-ayat Al-Qur'an terdiri dari 114 surah dalam 30 juz. Penyajiannya dilakukan secara urut sesuai sistematika penulisan AlQur'an dalam Mushaf Uṡmani yaitu dimulai dari Surah Al-Fatihah dan diakhiri dengan Surah AnNas. Pembahasan setiap Surah dalam Al-Qur'an selalu mengemukakan ciri-ciri khusus surah tersebut. Hal-hal yang disebutkan berkaitan dengan ciri-ciri surah, meliputi nama surah, 
nomor urut surah, jumlah ayat, kelompok turunnya Surah (Makkiyah/ᄀMadaniyah) dan urut-urutan Surah dalam proses turunnya. Penulisan tafsir ini ditulis secara sistematis, meliputi: Pertama, teks ayat-ayat Al-Qur'an dalam bahasa aslinya (Arab) yang ditulis di sisi kanan; Kedua, transliterasi bacaan AlQur'an dalam huruf latin yang ditulis di bawah teks asli; Ketiga, terjemah ayat-ayat Al-Qur'an dalam bahasa Jawa yang ditulis di sisi kiri; Keempat, keterangan atau penjelasan makna ayat Al-Qur'an dalam bahasa Jawa yang ditulis di bagian bawah dalam bentuk catatan kaki. Kelima, pointers penting berkaitan dengan topik-topik ibadah yang diberi judul "Katarangan Sawatis Ingkang Wigatos Murakabi"; Keenam, daftar pustaka

Di akhir pembahasan setiap Surah dikemukakan pokok-pokok pembahasan tentang hubungan antara kandungan Surah yang baru dibahas dengan kandungan Surah berikutnya yang akan dibahas. Secara umum, penjelasan dalam bentuk catatan kaki tersebut berisi keterangan mengenai makna ayat-ayat Al-Qur'an serta hikmah yang terkandung di dalamnya. Kadang-kadang penjelasan ini diberikan secara ringkas, namun tidak jarang pula diberikan dengan panjang lebar. Tidak setiap ayat Al-Qur'an diberi penjelasan. Sebaliknya penjelasan itu diberikan terhadap ayat-ayat Al-Qur'an yang dipandang membutuhkan keterangan lebih lanjut. Tentang ayat Al-Qur'an mana yang perlu diberi penjelasan dan mana yang tidak, pertimbangan sepenuh nya ada di tangan pengarang. Makna dan hikmah kandungan AlQur'an itu dikemukakan dengan bahasa yang sederhana dan lugas sehingga mudah dicerna dan dipahami oleh para pembaca, khususnya mereka yang memiliki latar belakang budaya Jawa.

\section{Metodologi Tafsir Al-Huda}

Dalam isi ringkas Tafsir Al-Huda tentang pengertian Al-Qur'an yang diuraikan oleh Bakri Sahid berisi bahwa: "Al-Qur'an kaya akan kisah-kisah penuh hikmah dan pelajaran, dan juga mengandung hukum secara umum yang menuntun dan memberi petunjuk kepada tiap-tiap individu untuk membangun ketakwaan kepada Allah dan menyempurnakan budi pekerti luhur serta budidaya manusia." ${ }^{13}$ Uraian tersebut mengisyaratkan bahwa terjemahan maupun penjelasan ayat-ayat Al-Qur'an pada dasarnya merupakan salah satu bentuk upaya Bakri Sahid dalam memahami Al-Qur'an agar dapat menjadi sarana bagi terwujudnya fungsi AlQur'an untuk membangun ketakwaan kepada Allah dan menyempurnakan budi pekerti luhur serta budidaya manusia.

Eksistensi Tafsir Al-Huda merupakan tafsir Al-Qur'an berbahasa Jawa yang berkaitan erat dengan hubungan dialektis antara nlai-nilai ajaran Al-Qur'an yang bersifat global normatif dengan nilai nilai budaya Jawa yang bersifat local historis. Tafsir Al-Huda berperspektif budaya Jawa yang bersifat cultural kontekstual serta akomodatif dan integrative interkonektif. Adapun metode dan corak penafsiran Tafsir AlHuda adalah sebagai berikut:

Tafsir Al-Huda melakukan terjemahan bebas secara tafsiriyyah dalam menjelaskan dan menyingkapkan makna ayat-ayat AlQur'an disesuaikan dengan pemahaman dan penalaran akal pengarangnya terhadap ayat-ayat Al-Qur'an yang diterjemahkan. Menafsirkan ayat-ayat Al-Qur'an secara ringkas dan sederhana, sehingga mudah dicerna dan dipahami oleh pembaca. ${ }^{14}$

Dalam menjelaskan ayat-ayat AlQur'an, Tafsir Al-Huda bercorak tafsir bir-ra'yi cenderung bersifat rasional menggunakan penalaran akal. Dalam penjelasan terhadap ayat-ayat Al-Qur'an, kadang-kadang Tafsir Al-Huda didukung dengan riwayat yang berkaitan dengan kandungan ayat atau Surah yang sedang dijelaskan, termasuk riwayat yang berhubungan dengan sebab turunnya (asbabun nuzul) tetapi tidak jarang penjelasan itu dilakukan dengan menggunakan penalaran akal semata-mata tanpa mengemukakan

\footnotetext{
${ }^{13}$ Ibid, h. 7

${ }^{14}$ M.Abdul Azhim al-Zarqani, t.th, Manahilul Irfan $f i$ Ulumil-Qur'an, Juz II, Beirut, DarulFikri, h. 111
} 
riwayat yang relevan. Fungsi riwayat hanya sebagai legitimasi bagi suatu penafsiran bukan sebagai titik tolak atau subjek. ${ }^{15}$

Secara metodologis langkah langkah penafsiran Al-Quran dalam Tafsir Al-Huda merupakan sebuah pendekatan yang dapat disebut pendekatan tsaqafi-ijtimai sosial budaya. Dengan pendekatan ini ayat-ayat AlQur'an dipahami berdasarkan konteks literer dan historisnya kemudian diproyeksikan dalam situasi dan kondisi masyarakat Jawa yang melingkupi lahirnya Tafsir Al-Huda berdasarkan sudut pandang budaya Jawa. Dialektika Al-Qur'an dan nilai nilai budi pekerti Jawa dalam Tafsir Al-Huda merupakan proses pergumulan antara Al-Qur'an warisan budaya Jawa yang dimiliki pengarang dan kondisi sosial budaya Jawa yang melingkupinya. Tafsir Al-Huda berperspektif budaya Jawa yang bersifat cultural kontekstual serta akomodatif dan integrative interkonektif. ${ }^{16}$

\section{Pendidikan Karakter dalam Tafsir Al- Huda}

Tafsir Al-Huda tafsir Al-Qur'an berbahasa Jawa yang merefleksikan proses pergumulan antara nilai-nilai akhlak mulia pada Al-Qur'an dengan nilai-nilai budi pekerti Jawa yang dimiliki pengarang dan kondisi sosial budaya Jawa yang melingkupi nya. Tafsir Al-Huda mentransformasikan nilai-nilai budi pekerti Jawa yang merupakan akumulasi dari ciptarasa-karsa yang diaktualisasikan ke dalam sikap, kata-kata, dan tingkah laku seseorang. 17. Budi pekerti yang merepresentasikan tabiat, watak, akhlak, dan moral, sekaligus mencerminkan sikap batin seseorang. Sikap batin yang akan terefleksi dalam tingkah laku seseorang. Pencerminan batin tersebut dalam wawasan religius disebut akhlakul karimah

15 Ali Hasan Al-'Aridl, 1994, Sejarah dan Metodologi Tafsir, Jakarta: PT. Raja Grafindo Persada, h. 48-49

${ }^{16}$ Saifullah, 2012, Nuansa Inklusif dalam Tafsir AlManar, Jakarta: Kementerian Agama, Balitbang Diklat, Puslitbang Lektur dan Khazanah Keagamaan, h. 36

17 Op.Cit, Tafsir Al-Huda, h. 351 (sikap dan tindakan yang mulia). (Suwardi Endraswara, 2006, 5)

Budi pekerti dalam pandangan Jawa berarti kesusilaan berperilaku luhur dan mulia yang merupakan pondasi dan dasar takwa kepada Allah. Atas kesadaran akan dan dengan melaksanakan nilai-nilai hidup kemanusiaan serta nilai-nilai hidup religius yang sewajarnya dan juga kebijaksanaan hidup, yaitu antara lain dengan melakukan tepa sarira secara negatif dan secara positif; secara negatif ialah tidak berfikir, berasa, berkehendak, bersikap, berbuat terhadap orang lain, yang tidak dikehendaki orang lain berfikir, berasa, berkehendak, bersikap berbuat terhadap orang lain, yang dikehendaki orang lain berfikir, berasa, berkehendak, bersikap, berbuat terhadap diri sendiri ${ }^{18}$

Menurut Bakri Sahid dalam Tafsir AlHuda, budi pekerti merupakan aktualisasi dari iman yang melahirkan nilai-nilai kepribadian luhur yaitu akhlak yang baik, rajin beribadah, jernih akal budinya, dan banyak berbuat kebajikan. (pitados ingkang yektos, gentur ibadahipun, sae budi-pekerti pun, wening nalar bebudenipun, kathah amal kasaenanipun). ${ }^{19}$ Budi pekerti merupakan tindak-tanduk perbuatan, tingkah laku (solah bawa), tutur kata (muna muni), tepat dalam bertindak (bawa-laksana); sesuai pada tempatnya (empan-papan); setiap saat berprasangka baik (kala-mangsa); cerdik dan berprasangka baik (duga-prayoga); kuat dan perkasa (teguh-tangguh). yang dilandasi kegiatan berpikir atau olah batin yang menghasilkan budi pekerti yang baik dan luhur mulia. ${ }^{20}$

Dengan berlandaskan iman dan takwa, padagilirannya akan muncul sikap-sikap utama seperti sabar, teguh pendirian (jatmika), ikhlas dalam menerima (nrima ing pandum), sederhana (bares dan prasaja), rendah hati (andham asor), luas pemikiran (lembah manah), dan kasih sayang (welas asih), jauh dari sikap adigang-

${ }^{18}$ Notonegoro, 1971, Pancasila Secara Ilmiah Populer, Jakarta: Pantjuran Tudjuh, h.4

${ }^{19}$ Op.Cit, Tafsir Al-Huda, h. 19

${ }^{20} \mathrm{Ibid}$, h. 689 
adigung-adiguna. Secara tegas Al-Qur'an Surah Luqman/31: 18-19 memerintahkan untuk berperilaku yang mulia adalah sederhana, tawadhu dan menjauhi sikap sombong, ${ }^{21}$

Lan poma sira aja malengo saka pipinira saka manungsa, kaya kalakuane wong gumedhe, lan sira aja lumaku ana ing bumi kalawan umuk (semangkean). Satemene Allah iku ora remen marang kabeh wong kang umuk tur kumalungkung. Lan sira padha diprasaja ana ing lumaku lan sapolahbawanira, lang nglirihna suwaranira, satemine ala alaning suwara iku suwaraning kuldi.

Dan janganlah kamu memalingkan wajah kepada manusia seperti jalannya orang pembesar dan kalian jangan berjalan di muka bumi sambil menyombongkan diri. Sungguh, Allah tidak senang terhadap orang yang angkuh lagi sombong. Dan hendaklah berlaku sopan dalam segala tindakan, dan rendahkanlah suaramu dalam pembicaraan. Sebenarnya sejelek-jelek suara adalah suara keledai. (Luqman/31:18-19)

Berjalan di muka bumi ini penuh dengan kerendahan hati, tidak menyombongkan diri, tidak angkuh atau menganggap dirinya "paling" dan "lebih" dari orang lain. Sederhana dan tidak berlebih-lebihan dalam berpenampilan, lemah lembut dalam ber tutur kata, ramah dalam berkomunikasi, santun dalam berperilaku, Menghargai pendapat orang lain ataupun menghormati sikap atau keputusan orang lain, tidak menghinanya, meremehkannya, dan memandangnya dengan mata kekecilan atau ia menolak perkara yang hak, padahal ia mengetahuinya.

Bakri Sahid memandang karakter lebih dekat dengan akhlak yaitu spontanitas manusia dalam bersikap atau melakukan perbuatan yang telah menyatu dalam diri manusia sehingga ketika muncul tidak perlu dipikirkan lagi. Akhlak berkaitan dengan tingkah laku hati, kebeningan dan kejernihan hati dan jiwa bersih dari segala sifat sifat tercela dan

${ }^{21}$ Ibid, h. 764 perbuatan maksiat. Akhlak meliputi akhlak yang baik ada yang jelek dan baik buruknya itu tergantung kepada baiknya jiwa atau nafsu yang melaksanakan. Akhlak sifatnya flexible dan dinamis dapat berubah total atau bolak balik karena berubah pendirian jiwa dan jiwa masing masing berubah tergantung oleh keadaaan yang mempengaruhi jiwa seperti keadaan pendidikan, pelajaran, atau perubahan zaman. Akhlak yang sudah mantap sulit berubah beda dengan yang masih melayang walau begitu kalau pengaruh luar lebih kuat pastinya akan dapat berubah. ${ }^{22}$

Karakter mulia dan utama akan muncul pada diri setiap individu utama jikalau telah ada padanya watak profetik, tidak memikirkan dirinya sendiri tetapi berpikir bagaimana dapat memberikan sesuatu bermanfaat sebanyakbanyaknya bagi lingkungan. Sebagaimana akhlak Rasulullah saw. yang merupakan suri tauladan dan perwujudan akhlak dan budi pekerti mulia seperti yang tertera dalam Surah al-Qalam/68: 4: "Lan satemene sira $i k u$ kadunungan bebuden luhur kang agung"'Dan sesungguhnya engkau benar-benar berbudi pekerti yang mulia"

Menurut filsafat Jawa, akhlak mulia Rasulullah merupakan perpaduan antara olah pikir, olah hati, olah raga, dan olah rasa yang merefleksikan empat karakter yang mulia, yaitu fathonah, shiddiq, amanah, dan tabligh. Dari empat karakter tersebut, dari sifat fathonah akan muncul jiwa yang cerdas, kreatif, inovatif, dan produktif; dari sifat shiddiq akan lahir jiwa-jiwa yang jujur, adil, bertanggung jawab, dan patriotik; dari sifat amanah muncul pribadi yang tangguh, sehat, kooperatif, disiplin, dan sportif; sedangkan dari sifat tabligh lahir pribadi yang peduli, ramah, santun, senang menolong dan toleran terhadap hak orang lain. ${ }^{23}$

Sedangkan menurut Bakri Sahid, akhlakul karimah ada empat bagian, yaitu:

\footnotetext{
${ }^{22}$ Ibid, h. 1212

${ }^{23}$ Purwadi, 2012, Pemikiran Religius Masyarakat Jawa, Yogyakarta: Elmaterapublishing, h. 37
} 
a. Hikmah, artinya semua perkara yang dicapai dengan akal dapat tercapai dengan secara kebetulan. Dari budi pekerti hikmah itu lalu tumbuh budi bersih, tajam ingatan, cerdas, dan senang berpikir.

b. Iffah, artinya perbuatan atau perilaku terhadap nafsu atau syahwat sudah teratur, terkontrol, tunduk kepada akal mengikuti aturan agama dari iffah lalu tumbuh sifat satria (luhur) pemalu, jujur, tenang, halus, rajin, teratur, bahagia, teliti dan tidak boros, beriman dan bertakwa (religius), berempati, dan berjiwa patriotik.

c. Syaja'ah artinya sifat nafsu sudah hilang tumpul pada akal menurut pada ketentuan agama. Dari budi pekerti saja'ah atau keberanian itu lalu tumbuh keluhuran tinggi budi pekerti kuat lagi teguh kemauannya, teguh dan tenang pemikirannya, tangguh menghadapi kesulitan sabar dan teliti, bijaksana dan arif serta berbudi wibawa, dan senang membantu kepada sesama, kooperatif dan bersahabat.

d. Adalah. Artinya nafsu sudah lurus, seimbang tidak berat sebelah, tidak melanggar aturan agama. Dari budi pekerti adil tumbuh sikap senang tenggang rasa, senang membalas kebajikan, saling kasih sayang sejati, senang ibadah kepada Allah pikiran nya tertancap selalu ingat kepada masjid, senang menghargai sesama, senang kepada kegiatan sosial dan persaudaraan serta menjalin persaudaraan dan silaturahmi dalam bentuk pertemuan, pertemanan atau perkumpulan. ${ }^{24}$

Pendidikan karakter dalam Tafsir Al-Huda juga mentransmisikan dan mem-budayakan model budaya Jawa yang didalamnya memuat nilai-nilai budi pekerti Jawa yang meliputi dua unsur, yaitu: pertama, ketauhidan (upaya mendekatkan diri kepada Tuhan Yang Maha Kuasa) dan kedua, kebajikan (upaya memberi

\footnotetext{
${ }^{24}$ Op.Cit, Tafsir Al-Huda, h. 303
}

petunjuk/ nasehat kepada siapapun yang berisi anjuran maupun larangan). ${ }^{25}$

Menurut Bakri Sahid pendidikan karakter yang mendasar dan penting untuk diterapkan dalam lingkungan keluarga maupun hubungan antarguru dan anak didik adalah mengucapkan salam. Memberi salam saat akan masuk ke rumah, ke masjid atau ke sekolah. Mengucapkan salam merupakan perilaku yang mulia dan sederhana yang penting dilestarikan dan diamalkan dalam kehidupan sehari hari. Sebagaimana firman Allah dalam Surah anNur/24: 27:

He wong-wong kang padha iman! Sira aja mlebu ing omah kang dudu omahira, kajaba yen sira wus anjaluk idzin lan uluk salam marang ahline! Kang kaya mangkono iku luwih becik tumrap sira, supaya sira padha ngeling-ngeling (ngestokna)!.

Wahai orang yang beriman! Janganlah kamu memasuki rumah yang bukan rumahmu sebelum meminta izin dan memberi salam kepada penghuninya. Yang demikian itu lebih baik bagimu agar kamu selalu ingat.

Mengucapkan salam sebagai salah satu bentuk tata krama saling hormat-menghormati antara yang lebih muda kepada yang lebih tua dan sayang-menyayangi antara yang lebih tua kepada yang lebih muda, bertegur sapa dan memberi salam keselamatan sebagai bentuk simpatik dan perhatian, bersikap sopan dan santun dalam berperilaku, lemah lembut dalam bertutur kata. Orang yang lebih tua memberi contoh teladan yang praktis dan mudah dipahami oleh anak dalam kehidupan sehari hari, mereka akan menuruti dan mengikuti teladan dan perilaku orang yang lebih tua. ${ }^{26}$

Dalam budi pekerti Jawa ada lima simbol untuk menilai karakter dan akhlak seseorang, yaitu: trapsila (baik tingkah lakunya), ukara (ramah dan jujur bicaranya), sastra (pintar

${ }^{25}$ Abdul Jamil, 2000, Islam dan Kebudayaan Jawa, Yogyakarta: Gama Media, h. 147

${ }^{26} \mathrm{Op}$. cit, Tafsir Al-Huda, h. 670 
dalam bekerja), susila (santun dan sopan), dan karya (baik hasil kerja nya). Memiliki watak yang baik, yaitu tri winasis (cerdas dan bijaksana), rereh (sabar dan mengekang diri), ririh (tenang tidak tergesa-gesa dalam mengambil keputusan), dan ngati-gati (selalu berhati-hati dalam segala tindakan). Selain itu juga menjauhkan diri dari sikap adigang adigung adiguna (menyombongkan diri). ${ }^{27}$ (Budiono, 1984, 147)

\section{Aplikasi Pendidikan Karakter dalam Tafsir Al-Huda}

Dalam pendidikan karakter, pikiran, perasaan, dan perilaku merupakan satu kesatuan yang utuh dalam pembentukan kepribadian dan pendewasan bagi anak didik. Knowing the good, loving the good, dan doing the good adalah merupakan sebuah entitas yang melekat secara integratif. Seseorang dinyatakan belum memiliki karakter yang baik jika hanya mempunyai pengetahuan tentang kebaikan, tetapi tidak mencintai kebaikan. Ada pula yang tahu dan cinta akan kebaikan, tetapi tidak melakukan kebaikan. Individu yang demikian juga belum menjadi insan yang berkarakter baik. ${ }^{28}$

Dalam Tafsir Al-Huda dikatakan bahwa pendidikan karakter merupakan per wujudan dari tridaya tiga kekuatan yang ada pada diri seseorang secara utuh dan menyeluruh dalam menggerakkan setiap aktifitas yang dilakukan. Tridaya meliputi cipta, rasa, dan karsa menyatu dan manunggal bergerak selaras, serasi, dan seimbang mewujudkan keinginan menjadi kenyataan. (Bakri Sahid, 1979, 351) Dalam struktur tata kefilsafatan Jawa, cipta berupa logika yang berupaya untuk memperoleh nilainilai kebenaran; rasa berbentuk estetika yang berupaya untuk memperoleh nilai keindahan; dan karsa berupa etika yang berupaya untuk memperoleh nilai kebaikan. Cipta-rasa-karsa,

\footnotetext{
${ }^{27}$ Herusatoto Budiono, 2003. Simbolisme dalam Budaya Jawa. Yogyakarta: Hanindita, h. 147

${ }^{28}$ Barnawi dan M. Arifin, 2011, Strategi dan Kebijakan Pembelajaran Pendidikan Karakter, Yogyakarta, Arruz Media, h.37.
}

logika-etika-estetika dan kebenaran-keindahankebaikan merupakan satu kesatuan yang dapat membuat kehidupan menjadi selaras, serasi dan seimbang seperti prasapa Sultan Agung dalam Serat Sastra Gendhing: mangasah mingising budi, memasuh malaning bumi. ${ }^{29}$

Tiga kekuatan pada diri seseorang berupa cipta-rasa-karsa terintegrasi dengan baik dapat merealisasikan terwujudnya pembentukan dan pendidikan karakter bagi anak didik. Pendidikan karakter tidak hanya mengajarkan mana nilai-nilai kebaikan dan mana nilai-nilai keburukan, tetapi lebih ditekankan kepada langkah-langkah penanaman kebiasaan (habitual) terhadap hal-hal yang baik. Sehingga setiap anak didik diharapkan mempunyai pemahaman tentang nilai-nilai kebaikan dan nilai keburukan, mampu merasakan nilai-nilai yang baik, dan mau melakukannya. ${ }^{30}$ (Asmaran, 1992, 8-9)

Adapun integrasi cipta-rasa-karsa dalam pembentukan pendidikan karakter berupa, yaitu:

1. Knowing the good (moral knowing), artinya anak mengerti baik dan buruk, mengerti tindakan yang harus diambil dan mampu memberikan prioritas hal-hal yang baik. Membentuk karakter anak tidak hanya sekedar tahu mengenai hal-hal yang baik, namun mereka juga harus dapat memahami kenapa perlu melakukan hal tersebut.

2. Feeling the good (moral feeling), artinya anak mempunyai kecintaan terhadap kebajikan dan membenci perbuatan buruk. Konsep ini mencoba membangkitkan rasa cinta anak untuk melakukan perbuatan baik. Pada tahap ini, anak dilatih untuk merasakan efek dari perbuatan baik yang dilakukannya. Sehingga jika kecintaan ini sudah tertanam, maka akan menjadi kekuatan yang luar basa dari dalam

${ }^{29}$ Suwardi, Endraswara, 2006, Budi Pekerti Jawa, Tuntunan Luhur dari Budaya Adiluhung, Yogyakarta: Buana Pustaka, h.136.

${ }^{30}$ Asmaran, 1992, Pengantar Studi Akhlak, Jakarta: RajaGrafindo Persada, h.8-9. 
diri anak untuk melakukan kebaikan dan "mengerem" atau meninggalkan perbuatan negatif.

3. Acting the good (moral action), artinya anak mampu melakukan kebajikan dan terbiasa melakukannya. Pada tahap ini anak dilatih untuk melakukan perbuatan baik, sebab tanpa melakukan sesuatu yang sudah diketahui atau dirasakan tidak akan ada artinya. ${ }^{31}$

Jika ketiga kekuatan cipta-rasa-karsa tertanam dan berperan aktif dalam diri setiap anak didik, maka akan tumbuhlah kesadaran untuk melaksanakan perbuatan/tindakan yang terpuji dan mulia yang kemudian menjadi kebiasaan dan rutinitas sehari-hari yang melekat di dalam setiap perilaku dan ucapan. Selain itu juga akan muncul kesadaran yang dapat mengendalikan dan menghindari anak didik untuk melakukan tindakan yang tercela dan merugikan dirinya sendiri maupun orang lain.

Sebagaimana penuturan KGPAA Mangkunegoro IV dalam Wedhatana bahwa ngelmu iku kalakone kanthi laku, lekase lawan kas, tegese kas nyantosani, santya budya pangekese dur angkara (ilmu itu terwujudnya dengan laku, dimulai dengan tekad yang bulat, makna yang bulat membawa kesontasaan sehingga menciptakan ketenangan budi yang pada akhirnya dan mampu menyingkirkan nafsu-nafsu rendah). Budi pekerti luhur diaktualisasikan dalam kehidupan sehari-hari dengan landasan eling lan waspada kelak akan mendapatkan pengayoman dan tuntunan dari Tuhan lahir-batin, jasmani-rohani, individusosial, materiil-spirituil, dan dunia-akhirat.

Menurut UU No 20 tahun 2003 pasal 3 menyebutkan Pendidikan Nasional ber fungsi mengembangkan kemampuan dan membentuk karakter bangsa yang bermartabat. Ada 9 pilar pendidikan berkarakter, diantaranya adalah: a, Cinta Tuhan dan segenap ciptaannya; b.

${ }^{31}$ Andi Agustan Arifin, 2010, Matinya Eksistensi Pendidikan, www.tribuntimur.com, h.1.
Tanggungjawab, kedisiplinan dankemandirian; c. Kejujuran/amanah dan kearifan; d. Hormat dan santun; e. Dermawan, suka menolong, gotong royong/ kerjasama; e. Percaya diri, kreatif dan bekerja keras; f. Kepemimpinan dan keadilan; g. Baik dan rendah hati; h. Toleransi kedamaian dan kesatuan ${ }^{32}$

Mengacu pada sembilan pilar pendidikan karakter yang dikembangkan oleh Kementerian Pendidikan dan Kebudayaan tersebut di atas, maka nilai-nilai pendidikan karakter dalam Tafsir Al-Huda yang relevan dalam pembentukan pendidikan karakter bagi anak didik di sekolah, antara lain, yaitu:

1. Religius. Sikap dan perilaku yang patuh dalam melaksanakan ajaran agama yang dianutnya, toleran terhadap pelaksanaan ibadah agama lain, dan hidup rukun dengan pemeluk agama lain. Dalam implikasinya anak didik secara terbiasa berdoa sebelum dan sesudah pelajaran. Mereka juga melaksanakan ibadah kepada Allah dan mereka salaing toleransi antarumat beragama dalam merayakan hari-hari besar keagamaan.

2. Jujur. Perilaku yang didasarkan pada upaya menjadikan dirinya sebagai orang yang selalu dapat dipercaya dalam perkataan, tindakan, dan pekerjaan. Implikasinya dalam pem belajaran, anak didik jujur dalam menyelesaikan soal-soal ujian dengan tidak menyontek kepada temannya dan juga jujur mengatakan atau menceritakan peristiwa yang dialami atau diamatinya, misalnya saat menemukan barang yang hilang.

3. Disiplin. Tindakan yang menunjukkan perilaku tertib dan patuh pada berbagai ketentuan dan peraturan. Implikasinya dalam kesehariannya di sekolah, anak didik datang ke sekolah tepat waktu, menyelesaikan tugas yang diberikan oleh guru, membiasakan mematuhi aturan sekolah misalnya mengenakan pakaian

${ }^{32}$ Kementerian Pendidikan Nasional Badan Penelitian dan Pengembangan Pusat Kurikulum, 2010, Pengembangan Pendidikan Budaya dan Karakter Bangsa, Jakarta 
seragam sekolah atau tertib dalam upacara bendera.

4. Kerja Keras. Tindakan yang menunjukkan perilaku tertib dan patuh pada berbagai ketentuan dan peraturan. Implikasinya dalam belajar di kelas, anak didik belajar dengan sungguh-sungguh, mengulang dan mendalami sesuatu yang dipelajarinya, dilihat, dan didengar. Berpikir dan melakukan sesuatu untuk menghasilkan cara atau hasil baru dari sesuatu yang telah dimiliki. Berkompetisi sehat antarteman dalam meraih prestasi dan menghargai hasil karya orang lain.

5. Peduli Lingkungan dan Peduli Sosial. Sikap dan tindakan yang selalu berupaya mencegah kerusakan pada lingkungan alam di sekitarnya dan mengembangkan upayaupaya untuk memperbaiki kerusakan alam yang sudah terjadi. Anak didik membiasakan diri memelihara kebersihan dan kelestarian lingkungan sekolah, misal tidak mencorat-coret dinding kelas. Anak didik berempati terhadap teman yang sedang dalam kesedihan/kesulitan, menolong teman yang dalam kesusahan. Mereka juga menciptakan suasana saling harga-menghargai, hormat-menghormati kepentingandan hak orang lain sehingga tercipta kerukunan dan keharmonisan dalam berkomunikasi dan berinteraksi antarsesama.

\section{PENUTUP}

\section{Kesimpulan}

Tafsir Al-Huda Qur'an Basa Jawi karya Bakri Syahid, Rektor IAIN Jogyakarta (19721977) salah satu khazanah tafsir Indonesia yang monumental yang berperspektif budaya lokal/Jawa yang bersifat cultural kontekstual serta akomodatiif dan integratif interkonektif. Eksistensi Tafsir Al-Huda merupakan tafsir AlQur'an berbahasa Jawa yang penerjemahanya bersifat tafsiriyyah dan bercorak tafsir bir-ra'yi cenderung bersifat rasional menggunakan penalaran akal. Secara metodologis, Tafsir Al-
Huda menggunakan pendekatan tsaqafi-ijtimai sosial budaya. memiliki corak sosial budaya yang sangat kental

Pendidikan Karakter dalam Tafsir Al-Huda mentransmisikan nilai-nilai budi pekerti Jawa yang merupakan akumulasi dari cipta-rasakarsa yang dilandasi kegiatan berpikir atau olah batin yang menghasilkan budi pekerti yang baik dan luhur mulia yang diaktualisasikan ke dalam tingkah laku (solah bawa), tutur kata (muna muni), bawa-laksana; empan-papan; kalamangsa; duga-prayoga; eguh-tangguh.

Jika tiga kekuatan cipta-rasa-karsa terintegrasi dengan baik, maka dalam pendidikan karakter akan membentuk pribadi anak didik yang knowing the good (mengerti apa yang baik baik dan buruk baginya), feeling the good (mencintai kebaikan dan membeci keburukan), dan actng the good (anak terlatih dan terbiasa melakukan hal-hak yang baik dan terpuji). Dengan pendidikan karakter akan muncul kesadaran pada anak didik untuk mengekspresikan pemahaman religiusitasnya dan mengaktualisasikan karakter yang mulia dan berakhlakul karimah dalam berkomunikasi maupun berinteraksi antarteman di sekolah maupun di lingkungannya.

\section{SUMBER BACAAN}

'Aridl, Ali Hasan, 1994, Sejarah dan Metodologi Tafsir, Jakarta: PT. RajaGrafindo Persada,

Asmaran, 1992, Pengantar Studi Akhlak, Jakarta: RajaGrafindo Persada.

Arifin, Andi Agustan, 2010, Matinya Eksistensi Pendidikan, www.tribuntimur.com.

al-Zarqani, M.Abdul Azhim, t.th, Manahilul Irfan fi Ulumil-Qur'an, Juz II, Beirut, DarulFikri,

Baidhawy Zakiyuddin, 2003, Inspirasi dan Apresiasi Islam dalam Budaya dan Seni, dan Mutohharun Jinan Agama dan Pluralitas Budaya Lokal, Surakarta: PSB-PS UMS.

Barnawi dan M. Arifin, 2011, Strategi dan Kebijakan Pembelajaran Pendidikan Karakter, Yogyakarta, Arruz Media. 
Budiono, Herusatoto, 2003. Simbolisme dalam Budaya Jawa. Yogyakarta: Hanindita.

Departemen Pendidikan Nasional, 2008. Kamus Besar Bahasa Indonesia. Jakarta: PT Gramedia Pustaka Utama, Edisi Keempat.

Dirjen Dikti, Pendidikan Karakter, www. kopertis8.0rg/.../Pendidikan\%20.

Jamil, Abdul, 2000, Islam dan Kebudayaan Jawa, Yogyakarta: Gama Media.

Kementerian Pendidikan Nasional Badan Penelitian dan Pengembangan Pusat Kurikulum, 2010, Pengembangan Pendidikan Budaya dan Karakter Bangsa, Jakarta

Krippendorf, Klaus, 1980, Content Analysis: AN Introduction to Its Methodology London Baverly Hills: Saga Publication

Megawangi, Ratna, 2008, Membangun SDM Indonesia Melalui Pendidikan Holistik Berbasis Karakter, www.usm.maine.edu.com dalam google.

Muhsin, Imam, 2010, Tafsir Al-Qur'an dan Budaya Lokal, Jakarta: Kementerian Agama, Balitbang Diklat, Puslitbang Lektur dan Khazanah Keagamaan, 2012
Purwadi, 2012, Pemikiran Religius Masyarakat Jawa, Yogyakarta: Elmatera Publishing.

Raharjo, Mudjia, 2012, Dasar-dasar Hermeneutika Antara Intensionalisme dan Gadamerian, Yogyakarta: Ar-Ruzz Media.

Saifullah, 2012, Nuansa Inklusif dalam Tafsir Al-Manar, Jakarta: Kementerian Agama, Balitbang Diklat, Puslitbang Lektur dan Khazanah Keagamaan.

Saliman, 2011, Membangun Karakter Bangsa Melalui Bahasa Simbolik Jawa, artikel.

Suseno, Frans Magnis, 1996, Etika Jawa, Jakarta: Gramedia Pustaka Utama.

Suwardi, Endraswara, 2006, Budi Pekerti Jawa, Tuntunan Luhur dari Budaya Adiluhung, Yogyakarta: Buana Pustaka.

Suwardi, Endraswara, 2013, Memayu Hayuning Bawana (Laku Menuju Keselamatan dan Kebahagiaan Hidup Orang Jawa), Yogyakarta: Narasi

Syahid, Bakri, 1979, Tafsir Al-Huda Tafsir Qur'an Basa Jawi, Yogyakarta: Persatuan Press 